Available online:

http://journal.imla.or.id/index.php/arabi

IMLA

Arabi : Journal of Arabic Studies, 3 (1), 2018, 61-69

DOI: http://dx.doi.org/10.24865/ajas.v3i1.72

\title{
PENGAWASAN DAN EVALUASI PROGRAM BAHASA ARAB DI PONDOK PESANTREN
}

\author{
Fitri Mawaddah Bako, Faiqatul Masruroh, Friske Tuli, Desiy Arifah \\ Universitas Islam Negeri Maulana Malik Ibrahim Malang, Indonesia \\ E-mail : faiqahmasrurah@yahoo.co.id
}

\begin{abstract}
This study identified how the supervision and evaluation of the Arabic program in the girl pesantren Hafsah Binti Umar Malang Batu. Data were collected through observation and interview. The subject of his research was two Arabic teachers at the pesantren. To get the data, the researcher conducted observation and interview directly to the Arabic teacher in the Pesantren where the researcher participated in observing the activit. Finally, this study concluded that the supervision of the Arabic language program at the girl pesantren Hafsah Binti Umar has not been fully done by the teachers since some of the programs that have been designed have not been written in the structure of the Pesantren Hafsah Binti Umar program. For the evaluation of the Arabic program, the chairman of the pesantren evaluated by asking each program that has been implemented to each teacher in their respective fields at the end of each semester.
\end{abstract}

Keywords: supervision, evaluation, Arabic program

Abstrak

Penelitian ini mengidentifikasi bagaimana pengawasan dan evaluasi program bahasa Arab di pondok putri Hafsah binti Umar. Data dikumpulkan melalui observasi dan wawancara. Subjek penelitiannya ialah guru bahasa Arab di Pesantren Hafsah binti Umar Malang Batu. Sedangkan sumber data dalam penelitian ini adalah 2 orang guru bahasa Arab di Pesantren Hafsah binti Umar Batu Malang. Untuk mendapatkan data, peneliti melakukan observasi dan wawancara langsung kepada guru bahasa Arab di Pesantren tersebut dimana peneliti ikut serta dalam mengamati kegiatan di pondok tersebut. Akhirnya, penelitian ini menyimpulkan bahwa pengawasan program bahasa Arab di pondok putri Hafsah binti Umar belum sepenuhnya dilakukan oleh guru pengajar dikarenakan sebagian program yang telah dirancang belum tertulis dalam struktur kegiatan program pesantren Hafsah binti Umar. Sedangkan untuk evaluasi program bahasa Arab yaitu ketua yayasan mengevaluasi dengan cara menanyakan setiap program-pogram yang telah terlaksana pada setiap guru di bidangnya masingmasing pada setiap akhir semester.

Kata Kunci: pengawasan, evaluasi, program bahasa Arab 


\section{Arabi : Journal of Arabic Studies}

\section{Pendahuluan}

Pada dasarnya rencana dan pelaksanaan merupakan satu kesatuan tindakan, meskipun pun hal ini jarang terjadi, pengawasan diperlukan untuk melihat sejauh mana hasil tercapai. Fungsi pengawasan merupakan suatu unsur menajemen untuk melihat apakah segala kegiatan yang dilaksanakan telah sesuai dengan rencana yang digariskan dan di samping itu merupakan hal yang penting pula untuk menentukan rencana kerja yang akan datang. Oleh karena itu, pengawasan merupakan suatu kegiatan yang perlu dilakukan oleh setiap pelaksana terutama yang memegang jabatan pimpinan. Tanpa pengawasan, pimpinan tidak dapat melihat adanya penyimpanganpenyimpangan dari rencana yang telah di gariskan dan juga tidak dapat menyusun rencana kerja yang lebih baik sebagai hasil dari pengalaman yang lalu. Sebuah perencanaan dikatakan baik jika ada pengawasan yang baik, sebaliknya tidak ada yang bisa diawasi bila tidak merencanakan sesuatu.

Adapun dalam tahap manajemen, evaluasi merupakan bagian yang tak terpisahkan dari suatu upaya apapun yang terperogram, tak terkecuali bagi program pembelajaran sebagai bagian dari program pendididikan dalam arti makro, evaluasi merupakan suatu proses menyediakan informasi yang dapat dijadikan sebagai pertimbangan untuk menentukan harga dan jasa dari tujuan yang dicapai, desain, implementasi, dan dampak untuk membantu membuat keputusan, membantu pertanggung jawaban dan meningkatkan pemahaman terhadap fenomena (Widoyoko, 2017).

Oleh karena itu sebuah program yang dilaksanakan dalam suatu lembaga harus memiliki sebuah rencana, dan untuk mengetahui apakah rencana tersebut sudah terlaksana atau belum terlaksana maka perlu adanya pengawasan dan evaluasi agar dapat segera mengetahui apa-apa saja yang belum dapat terealisasikan dalam program yang sudah direncanakan (Kurniawan, 2013).

Tindakan pengawasan dibutuhkan untuk memastikan dan mengevaluasi apa yang sudah diawasi, apa saja yang dicegah, dan apakah cara yang digunakan memang sudah efektif. Apapun yang kita lakukan haruskah worth-it, sepadan antara usaha dan manfaat (Widoyoko, 2017).

Artikel ini mengkaji suatu pengawasan dan evaluasi program yang terdapat di pondok Hafsah Binti Umar. Pondok Hafsah Binti Umar merupakan sebuah lembaga pembelajaran Tahfizul Quran dan Ta'Tim al-Lughah al-'Arabiyah, pondok ini memiliki sebuah program kegiatan yang telah dirancang oleh ketua yayasan lembaga tersebut. Program tersebut lebih mencanangkan pada kegiatan hafalan Al-Quran, namun demikian hal ini tidak membuat kegiatan atau program bahasa arabnya terabaikan, akan tetapi pondok ini memiliki beberapa kegiatan yang kurang berjalan dengan lancar, khususnya pada kegiatan atau program Bahasa Arab. Berdasarkan latar belakang di atas, penelitian ini bertujuan menjawab bagaimana pengawasan program bahasa Arab di Pondok Hafsah binti Umar dan bagaimana evaluasi program bahasa Arab di Pondok Hafsah binti Umar?

\section{Landasan Teori}

\section{Pengawasan}

1) Pengertian Pengawasan

Pada dasarnya rencana dan pelaksanaan merupakan satu kesatuan tindakan, walaupun hal ini jarang terjadi. Pengawasan diperlukan untuk melihat sejauh mana hasil tercapai. Menurut Murdick pengawasan merupakan proses dasar yang secara esensial tetap diperlukan bagaimanapun rumit dan luasnya suatu organisasi. Proses dasarnya terdiri dari tiga tahap:1) Menetapkan standar pelaksanaan. 2) Pengukuran pelaksanaan pekerjaan di bandingkan dengan standar. 3) Menentukan kesenjangan (deviasi) di antara pelaksanaan dengan standar dan rencana (Fattah, 2006).

Pengawasan merupakan suatu usaha sistematik untuk menetapkan standar pelaksanaan tujuan dengan tujuan-tujuan perencanaan, merancang sistem informasi umpan balik, membandingkan kegiatan nyata dengan standar yang telah ditetapkan sebelumnya, menentukan dan mengukur penyimpangan-penyimpangan serta mengambil tindakan koreksi yang diperlukan (Mutakallim, 2016). 
Secara umum terdapat dua tipe umum pengawasan yakni preventif dan korektif. Preventif adalah mekanisme untuk mengurangi atau meniadakan kesalahan, dengan mencegahnya. Sementara itu, pengawasan korektif adalah mekanisme mengurangi hasil dan prilaku yang tidak diinginkan.Semua ini dalam rangka perusahaan pada akhirnya mencapai kesesuaian dengan aturan rencana.

2) Proses Pengawasan

Dari pengertian yang telah di paparkan di atas, proses pengawasan terdiri atas dua tahap yaitu:

a. Menetapkan standar-standar pelaksanaan pekerjaan.Penentuan standar mencangkup kriteria untuk semua lapisan pekerjaan (job performance) yang terdapat dalam suatu organisasi. Standar ialah kriteria- kriteria untuk mengukur pelaksanaan pekerjaan.

b. Pengukuran Hasil/ Pelaksanaan Pekerjaan Tahap keduadari proses pengawasan adalah pengukuran hasil/ pelaksanaan.

3) Tujuan Pengawasan

Adapun tujuan pengawasan ditinjau dari konsep sistem ialah membantu mempertahankan hasil atau output yang sesuai dengan syarat-syarat sistem yang terdapat dalam sebuah pengawasan (Fattah, 2006).

Suatu pengawasan dapat dikatakan efektif jika memperhatikan beberapa hal berikut ini:

(1) Pengawasan harus di dikaitkan dengan tujuan, dan kriteria yang dapat digunakan untuk sistem pendidikan.

(2) Sulit, tetapi standar yang masih dapat dicapai harus ditentukan. Ada dua tujuan pokok yaitu: 1) untuk memotivasi 2) untuk dijadikan patokan guna membandingkan dengan prestasi. Artinya jika pengawasan ini efektif dapat memotivasi seluruh anggota untuk mencapai prestasi yang tinggi. Karena tantangan biasanya menimbulkan berbagai reaksi, maka daya upaya untuk mencapai standar yang sulit mungkin dapat membangkitkan semangat yang lebih besar untuk mencapainya.

(3) Pengawasan hendaknya disesuaikan dengan sifat dan kebutuhan organisasi. Disini perlu diperhatikan pola dan tata organisasi, seperti susunan, peraturan, kewenangan, dan tugastugas yang telah digariskan dalam uraian tugas (job description ).

(4) Banyaknya pengawasan harus dibatasi. Artinya jika pengawasan terhadap karyawan terlampau sering, maka akan ada kecendrungan mereka kehilangan otonominya dan dapat dipersepsi pengawasan itu sebagai pengekangan.

(5) Sistem pengawasan harus dikemudi (steering controls) tanpa mengorbankan otonomi dan kehormatan manajerial tetapi fleksibel, artinya sistem pengawasan menunjukkan kapan dan dimana tindakan korektif yang harus diambil.

(6) Pengawasan hendaknya mengacu pada tindakan perbaikan, artinya tidak hanya mengungkap penyimpangan dari standar tetapi penyediaan alternatif perbaikan, menentukan tindakan perbaikan.

(7) Pengawasan hendaknya mengacu pada prosedur pemecahan masalah, yaitu menemukan masalah, menemukan penyebab, membuat rancangan penanggulangan, melakukan perbaikan, mengecek hasil perbaikan, mengecek timbulnya masalah yang seruapa.

Untuk mengetahui dengan jelas penyelenggaraan berbagai kegiatan sesuai dengan rencana tekhnik yang dapat digunakan maka dilihat melalui:

a. Pengamatan langsung atau observasi oleh manajemen agar melihat sendiri bagaimana petugas operasional menyelenggarakan kegiatan dan menyelesaikan tugasnya. Teknik ini dapat berakibat sangat positif dalam implementasi strategi dengan efesien dan efektif karena dengan pengamatan langsung berbagai manfaat dapat dipetik.

b. Melalui laporan, baik lisan maupun tertulis dari para penyelia yang sehari-hari mengawasi secara langsung kegiatan para bawahannya dalam semua organisasi, penyampaian laporan dari seorang bawahan kepada atasannya merupakan hal yang bukan hanya biasa terjadi akan 


\section{Arabi : Journal of Arabic Studies}

tetapi sebuah keharusan. Dalam rangka pelaksanaan suatu strategi penyampaian laporan dari bawahan kepada atasannya harus memenuhi persyaratan sebagai berikut: penyampaian secara berkala yang frekuensinya tergantung pada "kebiasaan" yang berlaku pada organisasi dalam format yang sudah ditentukan, mengandung informasi yang sifatnya kritikal yang berarti tidak hanya menyajikan segi-segi positif dari pelaksanaan kegiatan operasional akan tetapi juga situasi negative yang perlu segera mendapat perhatian manajemen.

c. Melalui penggunaan kuisioner yang respondennya adalah para pelaksana kegiatan operasional.

d. Wawancara, apabila diperlukan wawancara dengan para penyelenggara berbagai kegiatan operasional dapat dilakukan dalam rangka pengawasan (Fattah, 2006).

\section{Evaluasi}

1) Pengertian Evaluasi

Evaluasi berasal dari kata evaluation, kata ini diserap dalam perbendaharaan bahasa Indonesia dengan tujuan mempertahankan kata aslinya dengan sedikit penyesuaian pelafalan menjadi "evaluasi" (Rohman, 2014). Pemahaman tentang evaluasi secara umum adalah untuk memperbaiki atau mengembangkan rencana pembelajaran dan kegiatan-kegiatan pembelajaran yang baru, seperti komunikasi untuk kegiatan pembelajaran (al-Syamikh, 2018).

Evaluasi program merupakan suatu proses pencarian informasi, penemuan informasi dan penetapan informasi yang dipaparkan secara sisitematis tentang perencanaan, nilai, tujuan, manfaat, efektivitas dan kesesuaian sesuatu dengan kriteria dan tujuan yang telah ditetapkan (Munthe, 2005). Evaluasi adalah pembuatan pertimbangan menurut suatu perangkat kriteria yang disepakati dan dapat dipertanggungjawabkan. Menurut TR Morrison (Abdjul, 1982) ada tiga faktor penting dalam konsep evaluasi, yaitu: pertimbangan (judgement) deskripsi obyek penilaian, dan kriteria yang tertanggung jawab (defensible criteria). Aspek keputusan itu yang membedakan evaluasi sebagai suatu kegiatan dan konsep dari kegiatan dan konsep lainnya, seperti pengukuran (measurement) (Fattah, 2006). Pengkajian tentang evaluasi disini lebih terfokus pada evaluasi program karena dikaitkan dengan kepentingan pimpinan/manajer.

\section{2) Macam-macam Evaluasi}

Secara umum evaluasi dapat dibedakan atas dua jenis, yaitu evalusi formatif dan evaluasi sumatif (Supriyanto, 2006).

Evaluasi formatif: evaluasi yang dilakukan pada tahap pelaksanaan program dengan tujuan untuk mengubah atau memperbaiki program yang sedang berjalan dan didasarkan atas kegiatan sehari-hari, minggu, bulan bahkan tahun atau waktu relative pendek. Manfaat evaluasi formatif terutama untuk memberikan umpan balik kepada manager program tentang kemajuan hasil yang dicapai beserta hambatan-hambatan yang dihadapi. Evaluasi formatif sering disebut evalusi proses atau monitoring.

\section{Evaluasi formatif $\longleftrightarrow$ saat pelaksanaan program}

Evaluasi sumatif: evaluasi yang dilakukan untuk melihat hasil keseluruhan dari suatu program yang telah selesai dilaksanakan. Evaluasi dilakukan pada akhir kegiatan atau pada atau beberapa kurun waktu setelah program, guna menilai keberhasilan program. Hasil evaluasi dapat memberikan jawaban atas pertanyaan; apakah tujuan program dapat tercapai atau tidak dan alasan-alasan mengapa demikian. Karena itu keluaran (output) program berupa efek hasil keluaran (outcome) dan dampak sangat diperlukan.

Evalusai sumitif $\longleftrightarrow$ setelah program/tahun anggaran selesai berikut:

Bagaimana kerangka dasar evaluasi program. Secara sederhana dapat dibagankan sebagai

1) Unsur-Unsur Program 
Arabi : Journal of Arabic Studies

Pada umumnya, unsur program dapat ditentukan dengan dua cara pendekatan, yaitu pendekatan struktural dan fungsional. Unsur-unsur program suatu pendekatan struktural:a) tujuan program. b) seleksi dasar kegiatan belajar. c) rasional dan pendekatan terhadap evaluasi. d) karakteristik siswa (kemampuan).

Kerangka Dasar Evaluasi Program

\begin{tabular}{l}
\hline Susun Kerangka Acuan (Terms of Reference) Bagi evaluasi \\
\hline 1) Tujuan evaluasi \\
2) Peranan evaluasi, yakni untuk apa hasil evaluasi itu digunakan. \\
3) Kendalanya \\
4) Penunjangnya \\
\hline Tentukan Unsur-unsur Program \\
\hline 1) Struktural \\
2) Fungsional
\end{tabular}

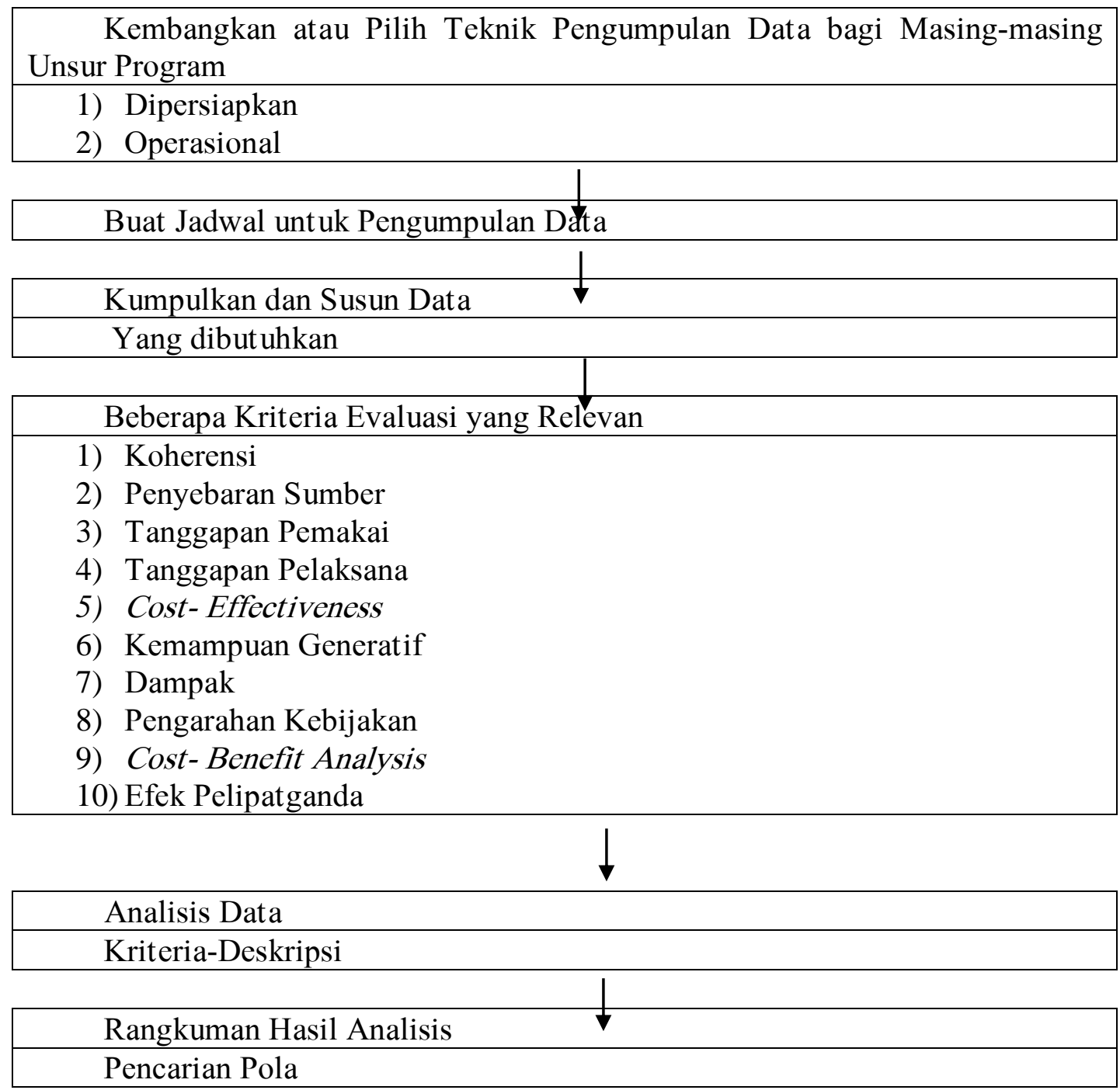

Sumber: TR. Morrison, Description-Criteria, Judgement, P3G), Depdikbud, Jakarta, 1982.

Sedangkan pendekatan fungsional dapat dipertimbangkan dalam menilai keseluruhan program suatu sekolah. Berbeda dengan pendekatan struktural yang mementingkan komponen utama, tetapi pendekatan fungsional menekankan pada fungsi-fungsi utama dari suatu program, 


\section{Arabi : Journal of Arabic Studies}

misalnya: Evaluasi dan seleksi, Diagnosis dan remedial, Penjadwalan, Kompetensi fisik, Fungsi kepustakaan/sumber bacaan, Penempatan kerja, Latihan jabatan, Testing.

2) Pengumpulan Data Unsur Program

Kegiatan yang diperlukan adalah mengumpulkan data tentang program dan mengorganisasi bahan secara sistematik. Deskripsi program dibedakan dua tingkat yaitu, persepsi dan realitas. Persepsi merupakan apa yang dipandang oleh orang-orang yang dikenai program merupakan hakikat program. Realita adalah berdasarkan observasi terhadap program, apakah yang dipandang evaluator merupakan tujuan aktual program. Teknik pengumpulan data untuk persepsi dan operasional/realita untuk setiap unsur program dapat dibedakan sebagai berikut.

Contoh: Teknik Koleksi Data

\begin{tabular}{|c|c|c|}
\hline Unsur & Persepsi & Operasional \\
Program & & Observasi langsung \\
\hline Observasi & Kuesioner Interviu & Analisis hasil Interviu \\
Kegiatan & Analisis dokumen & Analisis interaksi \\
belajar & & Etnografi Simulasi \\
Seleksi isi & & Catatan harian Teknik \\
Evaluasi & & kritikal insiden \\
Iklim & & \\
Karakteristik & & \\
siswa & & \\
Penunjang & & \\
administrasi & & \\
Gaya & & \\
interpretasi & & \\
\hline
\end{tabular}

3) Kriteria Evaluasi

Ada beberapa kriteria yang dipilih untuk digunakan dalam evaluasi yang berfungsi sebagai acuan pengkajian. Jika kerangka acuan spesifik, misalnya mengevaluasi segi-segi efisiensi ekonomis maka seperangkat kriteria yang relevan akan dipilih untuk dipergunakan. Jika kerangka acuan luas dan tidak didefinisikan, misalnya evaluasi sebanyak mungkin aspek-aspek program, maka evaluator memilih lebih banyak perangkat kriteria yang relevan.

Ada dua jenis kriteria yang dapat dipergunakan dalam evaluasi program, yaitu kriteria internal dan eksternal. Kriteria internal adalah standar yang dapat diaplikasikan terhadap suatu program dalam kerangka program itu sendiri. Kriteria eksternal adalah standar yang diterapkan terhadap suatu program dari suatu sumber di luar kerangka program.

Evaluasi atau kegiatan penilaian merupakan bagian integral dari fungsi manajemen dan didasarkan pada sistem informasi manajemen.Evaluasi dilaksanakan karena adanya dorongan atau keinginan mengukur pencapaian hasil kerja atau kegiatan pelaksanaan program terhadap tujuan yang telah ditetapkan.Evaluasi dimaksudkan untuk mendapatkan informasi yang relevan guna pengambilan keputusan (Supriyanto, 2006).

\section{Metode Penelitian Data}

Penelitian ini menggunakan metode penelitian kualitatif deskriptif. Data yang dikumpulkan adalah berupa hasil wawancara, dan observasi yang tidak menggunakan angka (Sugiono, 2017). Subjek penelitiannya ialah guru bahasa Arab di Pondok Hafsah binti Umar Malang Batu. Adapun sumber data dalam penelitian ini adalah guru bahasa Arab di Pondok Hafsah binti Umar Batu Malang yang berjumlah 2 orang. Untuk mendapatkan data peneliti melakukan observasi langsung kepada guru bahasa Arab di Pondok tersebut di mana peneliti ikut serta dalam mengamati kegiatan di pondok tersebut. Dan juga mewawancarai langsung guru Bahasa Arab Pondok Hafsah binti Umar. Metode penelitian ini menggunakan pendekatan Riset naratif, menurut Czarniawska (2004), 
riset naratif merupakan tipe disain kualitatif yang spesifik yang narasinya dipahami sebagai teks yang dituturkan atau dituliskan dengan menceritakan tentang peristiwa/aksi yang terhubung secara kronologis (Creswell, 2014). Setelah data dari observasi dan wawancara terkumpul maka tahap selanjutnya menganalisis data. Data yang sudah didapat dari Pondok tersebut terkait dengan pengawasan dan evaluasi program bahasa Arab, kemudian di analisis agar dapat mempermudah peneliti dalam pemaparan data.

\section{Hasil Penelitian}

1. Pengawasan program bahasa Arab di pondok Hafsah binti Umar

Penelitian ini dilaksanakan di Pondok Hafsah binti Umar tepatnya di Jl Semeru kecamatan Sisir, Batu, Malang. Pondok ini baru berdiri selama 2 tahun. Pondok ini merupakan pondok yang berbasis pada program Tahfizul Quran, Ta'lim al-Lughah al-'Arabiyah dan hanya diperuntukkan bagi santriwati yang duduk dibangku SMP dan SMA. Penelitian ini difokuskan pada kegiatan atau program bahasa Arab. Santriwati di Pondok ini berjumlah 35 orang sedangkan jumlah pengajar yang sudah sarjana berjumlah 8 orang. Penelitian ini dilakukan pada dua pengajar bahasa Arab di sekolah tersebut.

Secara konseptual dan filosofis, pentingnya pengawasan berangkat dari kenyataan bahwa manusia penyelenggara kegiatan operasional merupakan makhluk yang tidak sempurna dan secara inheren memiliki keterbatasan, baik dalam arti interpretasi makna suatu rencana, kemampuan, pengetahuan, maupun keterampilan. Artinya dengan itikad yang paling baik, dedikasi dan loyalitas yang tinggi dan pengerahan kemampuan mental dan fisik sekalipun, para penyelenggara kegiatan operasional mungkin saja berbuat khilaf dan bahkan mungkin berbuat kesalahan. Kenyataan menunjukkan bahwa tidak semua anggota organisasi yang selalu menampilkan perilaku demikian. Sengaja atau tidak, prilaku negatif adakalanya muncul dan berpengaruh pada kinerja seseorang yang factor-faktor penyebabnya beraneka ragam. Mengahadapi kemungkinan demikianlah pengawasan mutlak perlu dilakukan (Siagian, 2011).

Sesuai dengan pengertian, proses dan tujuan pengawasan bahwa sebuah pengawasan itu sangat dibutuhkan agar dapat melihat sejauh mana sudah berjalannya suatu perencanaan yang sudah direncanakan, maka akan dideskripsikan dan dipaparkan bagaimana pengawasan program bahasa Arab di pondok tersebut agar dapat menjawab tujuan dari program tersebut (Sa'diyah, 2016). Sebelum melihat program bahasa Arab maka perlu dilihat terlebih dahulu rencana yang telah di susun oleh ketua yayasan pondok tersebut agar dapat mengetahui apakah program tersebut sudah berjalan atau tidak.

Adapun perencanaan program di pondok Hafsah binti Umar adalah sebagai berikut:

1. Merancang pembagian Materi untuk 3 tahun. Adapun Materi yang diajarkan adalah sebagai berikut: Aqidah, Sirah, Hadis, Tafsir, Fiqh, Tajwid, Bahasa Arab, Nahwu, Sharaf, Ta'bir, dan Kitabah. dan kebanyakan dari pelajaran-pelajaran tersebut terdapat 3 jilid buku, yang mana setiap jilidnya disesuaikan dengan jenjang masing-masing.

2. Membuat jadwal ekskul. Minggu pertama berenang, minggu kedua memasak, minggu ke tiga perpulangan, dan minggu ke empat menjahit.

3. Membuat program harian, salah satu program bahasa Arab yang digerakkan ialah mengadakan mufrodat setelah sarapan pagi Pukul 07.00 (Wakil Mudhirah, 2018). Hal ini agar menunjang santriwati untuk menggunakan bahasa Arab.

Berdasarkan program- program yang tertera tersebut maka peneliti mewawancarai salah satu guru bahasa Arab di pondok tersebut,

Peneliti : apakah pembagian materi atau pelajaran yang sudah direncanakan sudah berjalan?

Guru : untuk sekarang ada beberapa mata pelajaran yang tidak lagi digunakan, seperti ta'bir, hal ini dikarenakan sulitnya bagi tingkat pemula untuk memahami materi tersebut.

Peneliti : apakah Mufradat yang diberikan menunjang santriwati untuk berbahasa Arab ? 


\section{Arabi : Journal of Arabic Studies}

Guru : ya tentu saja, walaupun terkadang bahasa yang mereka sampaikan masih mengartikan kata demi kata.

Peneliti : bagaimana cara para pengajar bahasa Arab untuk meningkatkan keterampilan berbahasa anak?

Guru : menghidupkan lagu-lagu yang berbahasa Arab, baik bahasa Arab yang 'ammiyah dan fusha.

Peneliti : apakah ada pengawasan yang dilakukan untuk meningkatkan program bahasa Arab di Pondok Hafsah binti Umar?

Guru : untuk pengawasan sudah dilaksanakan, seperti melihat sejauh mana sudah santriwati menggunakan bahasa jika ditinjau dari segi bahasa.

Berdasarkan hasil wawancara di atas, pengawasan program bahasa Arab sudah dilaksanakan meskipun ada beberapa hal yang harus lebih diperhatikan oleh guru yaitu hendaknya guru membuat kegiatan bahasa arab yang dapat menunjang mereka untuk lebih tertarik pada program bahasa Arab seperti, adanya lomba pidato bahasa bahasa Arab, adanya permainan yang berbasis bahasa Arab yang mana kegiatan tersebut dilakukan selama sebulan sekali.

2. Evaluasi program bahasa Arab di pondok Hafsah Binti Umar

Adapun evaluasi program yang dilakukan di pondok tersebut ialah ketua yayasan menanyakan pada setiap guru yang mengajar dibidangnya masing-masing, khususnya guru bahasa Arab. Seperti menanyakan tentang bagaimana progress pembelajaran yang sudah disampaikan, Apakah para santri dapat menerima materi atau pembelajaran dengan baik, sehingga dengan ini ketua yayasan dapat menimbang atau menilai atau mengevaluasi apa yang harus diperbaiki untuk program ke depannya.

\section{Pembahasan}

1. Pengawasan program bahasa Arab di pondok Hafsah Binti Umar

berdasarkan hasil observasi, wawancara dan hasil pengamatan, pengawasan program bahasa Arab di pondok Hafsah binti Umar belum sepenuhnya dilakukan oleh guru pengajar dikarenakan sebagian program yang telah dirancang belum tertulis dalam struktur kegiatan program pondok Hafsah Binti Umar, seperti aktivitas santriwati dalam berbahasa, hendaknya para guru lebih memperhatikan atau lebih mengawasi bahasa yang digunakan oleh santriwati sehingga mereka dapat meminimalisir kesalahan-kesalahan berbahasa yaitu bahasa Arab. Oleh karena itu, semestinya guru tidak hanya memberikan mufradät, melainkan memberi kegiatan kegiatan yang berkaitan dengan bahasa Arab seperti Pidato bahasa Arab, membuat permainan-permainan yang berbahasa Arab, atau mengadakan kegiatan drama dll, yang dapat meningkatkan program-program bahasa Arab (Jubaidah, 2015).

Menurut Murdick pengawasan merupakan proses dasar yang secara esensial tetap diperlukan bagaimanapun rumit dan luasnya suatu organisasi. Proses dasarnya terdiri dari tiga tahap:1) Menetapkan standar pelaksanaan. 2) Pengukuran pelaksanaan pekerjaan di bandingkan dengan standar. 3) Menentukan kesenjangan (deviasi) diantara pelaksanaan dengan standar dan rencana (Fattah, 2006). Dari ketiga tahap ini, pondok hafsah binti umar hanya menggunakan dua tahap, yaitu tahap pertama menetapkan standar pelaksanaan dan tahap yang kedua Pengukuran pelaksanaan pekerjaan dibandingkan dengan standar.

2. Evaluasi program bahasa Arab di pondok Hafsah binti Umar

Berdasarkan program evaluasi yang dilakukan oleh ketua yayasan dapat dilihat bahwa ketua yayasan mengevaluasi dengan cara menanyakan setiap program-pogram yang telah terlaksana pada setiap guru di bidangnya masing-masing pada setiap akhir semester.

Menurut Stefanus Supriyanto dan Nyoman Anita Damayanti (2006) secara umum evaluasi dapat dibedakan atas dua jenis, yaitu evalusi formatif dan evaluasi sumatif. 
1. Evaluasi formatif: evaluasi yang dilakukan pada tahap pelaksanaan program dengan tujuan untuk mengubah atau memperbaiki program yang sedang berjalan dan didasarkan atas kegiatan sehari-hari, minggu, bulan bahkan tahun atau waktu relative pendek.

2. Evaluasi sumatif: evaluasi yang dilakukan untuk melihat hasil keseluruhan dari suatu program yang telah selesai dilaksanakan.

Dari kedua macam evaluasi tersebut, pondok hafsah binti umar menggunakan evaluasi Sumatif.

\section{Simpulan}

Berdasarkan hasil analisis data diatas, peneliti dapat menyimpulkan bahwa sebuah pengawasan dan evaluasi itu sangat perlu dilakukan untuk menjalankan rencana-rencana yang telah disusun sebelumnya, baik rencana jangka panjang maupun rencana jangka pendek yang dapat memajukan program kegiatan sebuah lembaga dan meningkatkan kualitas sebuah lembaga ataupun sekumpulan organisasi. Pengawasan merupakan wadah untuk dapat mengoreksi atau memperbaiki mana kegiatan-kegiatan atau program program yang sudah terlaksana atau belum terlaksana, dan dengan adanya pengawasan maka perencanaan yang sudah disusun dapat terkontrol dengan baik. Adapun evaluasi menjadi bahan untuk dapat menilai bagaimana hasil program yang telah tersusun dalam sebuah perencanaan program bahasa Arab, dan menjadi bahan pertimbangan dalam menentukan hal-hal apa saja yang sekiranya pantas dan perlu di tambah, atau mengurangi program yang semestinya harus di kurangi demi kemajuan sebuah lembaga. Program bahasa Arab yang ada di pondok tersebut masih sedikit, hendaknya perlu ada program tambahan yang dapat mendukung santriwati untuk meningkatkan kemampuan dalam bidang bahasa Arab.[]

\section{Daftar Rujukan}

Asrori, Imam. dkk. 2006. Evaluasi pembelajaran Bahasa Arab, Malang: Misykat.

Creswell, John W. 2014. Penelitian Kualitatif \& Desain Riset, Yogyakarta, Pustaka Pelajar.

Fattah, Nanang. 2006. Landasan Manajemen Pendidikan, Bandung: PT. Remaja Rosdakarya.

Jubaidah, Siti. 2015. "Pembelajaran dan Pemerolehan Bahasa Arab di Pondok Modern Gontor di Darul Ma'rifat Gurah Kediri Jatim”, Jurnal Parameter, Vol. 27, No. 2.

Kurniawan, Dody. 2013. "Evaluation on Foreign Language Development Program", Jurnal Evaluasi Pendidikan, Vol. 4, No. 1.

Munthe, Ashiong P. 2005. "Pentingnya Evaluasi Program di Institusi Pendidikan", Jurnal Scholaria, Vol. 5, No. 2.

Mutakallim. 2016. "Pengawasan Evaluasi dan Umpan Balik Stratejik", Jurnal Inspiratif Pendidikan, Vol. V, No. 2.

Rohman, Fathur. 2014. "Strategi Pengelolaan Komponen Pembelajaran Bahasa Arab", Arabiyat: Jurnal Pendidikan Bahasa Arab dan Kebahasaaraban, Vol. 1, No. 1.

Sa'diyah, Zaimatus. 2016. "Evaluasi Pengajaran Bahasa Arab di STAIN Kudus (Upaya untuk Menemukan Bentuk Ideal Pengajaran Bahasa Arab)", Jurnal Penelitian, Vol. 10, No. 2.

Siagian, Sondang P. 2011. Manajemen Stratejik, Jakarta: PT Bumi Aksara.

Supriyanto, Stefanus. Damayanti Nyoman Anita. 2007. Perencanaan dan Evaluasi, Surabaya: Airlangga University Press.

Taufiq, Amir. 2006, Belajar Manajeman dari Konteks Dunia Nyata, Yogyakarta: Graha Ilmu.

Widyoko, Putro Eko. 2017. Evaluasi Program Pembelajaran, Yogyakarta: Pustaka Pelajar. 